\section{Quinary Music}

Mr. Jevons, in his interesting paper on the Limits of Numerical Discrimination (NATURE, Feb. 9), asserts in support of his views (Rees Cyc. "Rhythm") that "no musicians have yet been found capable of performing " quinary music.

I have never found the slightest difficulty, nor can I conceive any, either in performing or inventing music subdivided into five isochronous measures, i.e., with an accent recurring on every fifth unit of measure; nor do I see anything to justify his doubt that the ear can grasp divisions of $6,8,9$, without regrouping them into smaller periods; as amongst skilled musicians there exists no doubt whatever about the continuous reading of those larger groups, without even a suggestion of such subdivision; and it would be easy to multiply quotations from the best writers of passages whose only correct performance and reception by the listeners would be entirely destroyed by such a sub-grouping as Mr. Jevons seems to think necessary.

Apropos:-I greatly doubt whether the question of musical time is at all pertinent to the subject of numerical discrimination, as an instantaneous conception; the latter being a synchronous mental act, while the former is altogether consecutive in its operation, in which every group, however small, is only a sequence of units.

38, Synge Street, Dublin, Feb. I4

\section{The Power of Numerical Discrimination}

IN an article with this title in a recent number of NATURE, Mr. W. S. Jevons offered the results of some ingenious experiments he had been making to determine how many objects the human mind could count by an instantaneous and apparently single act of attention. He comes to the conclusion that the power of his mind was limited to something less than five.

If it were Prof. Jevons' purpose to ascertain the number of objects he could count within an interval too short for more than assingle conscious act of attention, his experiments were, doubt. less, conclusive, at least to him ; but if he sought through them to prove that he or any other person could fix his attention upon more than one object at a time, I fancy he commits the mistake attributed to the Royal Society in puzzling over the question put them by Charles I. about the effect of throwing a shrimp into a pail full of water. He is trying to account for a phenomenon that never occurred and which can never occur.

Prof. Dugald Stewart, in his work on the "Philosophy of the Human Mind "* has proved very clearly, it seems to me, that the attention is never fixed upon two points or objects at the same time, but that it passes from one to another in certain cases, as in playing upon musical instruments, in feats of jugglery, \&c., so rapidly as to seem to be instantaneous.

In addition to what Prof. Stewart has said upon this subject, permit me to ask how it is any more possible for the attention to be fixed on two beans at one time than for two beans to be in the same place at the same time? The argument that could demonstrate the absurdity of the last of these propositions would demonstrate the absurdity of the first.

If Mr. Jevons will try to look at both eyes at once of the first person he talks with, he will find that one of the eyes seems more distinct to him than the other, and every effort he may make to equilibriate his attention will only result in changing it from one to the other.

If he is talking with great earnestness, or in a way to make his interlocutor very anxious to divine his meaning and penetrate or anticipate the expression of his inner thougbts, he will notice that his interlocutor's eyes seem to be running from one of his own eyes to the other, as if in hopes of getting from one some disclosures not made by the other. This would not be done if both eyes could be seen simultaneously.

Mr. Jevons seemed to see five beans, because he was able to run over and count five in the minimum of conscious time.

I think there is no authority for saying that there is any period of conscious time necessary for any purely mental operation. To the mind itself, or the spirit of a man, there is neither space nor time. There are incidents of our material organisation which limit our capacity to notice and remember mental operations, but not the operations themselves. Therefore the rapidity with which the attention is transferred from one word to another in reading, or from one key to another of a piano when played by

* Works of Dugald Stewart. Edited by Sir William Hamilton. Art. "Attention." a master, authorises no presumption whatever that his attention is ever fixed upon more than one key at a time, while all the piesumptions are against the possibility of any person's attention ever being in two places at the same moment.

Berlin, March 4

\section{Eozoön Canadense}

ON a careful consideration of Dr. Dawson's reply to the objections urged by me against the supposed organic nature of Eozoön Canadense, I confess my inability to see that one single fact is brought forward calculated to shake the position of those who regard it as a purely mineral production.

In opposition to all previously received opiuion, Dr. Dawson would now confine Eozoön to the Laurentian period. I am glad to accept this as evidence that its Canadian discoverers begin to feel the force of the "difficulties" I have stated, and instead of ignoring them, make a genuine and direct attempt to meet them.

Though Dr. Hunt now doubts the accuracy of the observations which refer the Skye ophite to the Lias, he has elsewhere as good as admitted that it is not confined to the Laurentian period.* Giimbel has also determined it for Cambrian metamorphic rocks in the Fichtelgebirge, Bavaria, and Rupert Jones and Sandford for rocks of the Lower Silurian period in Connemara, as pointed out by Mr. Kinahan in his letter in NATURE (No. 66). The Tudor specimen, it is also considered, may belong to the Cambrian or Potsdam group. This, to say the least, is somewhat contradictory.

The determination of the age of the Skye ophite I am willing to leave Dr. Hunt to settle with Professors King and Rowney, merely remarking that both $\mathrm{McCulloch}$ and Geikie, as inclependent observers not looking for evidence in support of a theory, declare the rock to be of the Liassic age.

The lengthy disputes as to what is to be considered Eozoön and what is not, are most amusing. When each disputant takes up a different position and shifts it as occasion requires, how is he to be met? And is this not of itself sufficient primis facie evidence of weakness such as to warrant a suspension of judgment on the part of those-and their number is great-who have accepted the "fossil" only on the strength of eminent names and reiterated assurances?

As far as I can make out, the whole positive evidence is now narrowed down to the determination of what is and what is not the true "nummuline layer." A reference to the published figures and descriptions gives no information by which we may detect any difference between the "nummuline layer" of the Skye ophite and that of the typical Canadian specimens. Thus, then, until Dr. Dawson points out the difference, this objection cannot be said to be "wholly irrelevant." To aver, without proof, that when the characteristic structure occurs in an unlookedfor position, that it is an initiative form, or, on the contrary, to assume it to be a fossil when discovered elsewhere, is easy, but does not tend to carry conviction to the unbiassed mind. To do this, we require distinct and ample evidence. The Eozoön before referred to as discovered by Mr. Sandford in the Connemara ophite, and "verified" by Rupert Jones, $\dagger$ belongs, according to Murchison, to the Lower Silurian age. $\neq$ The discovery, it appears, had at the time induced Sir Roderick to class this rock as Laurentian, but shortly afterwards, purely from stratigraphical considerations, he pronounced it to be Lower Silurian.\$ Here, again, we have a discordance with the views of Dr. Dawson; are we, then, to throw away such independent testimony, and say that the unfortunate Eozoön "Hibernicum" is an imitative form, or, are we to consider the veteran geologist wrong, and the Connemara marble Laurentian?

It is now seen that all the theories which attempt to meet the objections I have stated are in conflict-which then is right?

As regards the Tudor specimen, which, it is thought, I have too summarily "disposed" of, I would observe that it was brought forward with great éclat as a conclusive answer to all objections founded on the comparison of the structures of Eozoön with the forms of fibrous, dendritic, or concretionary minerals. The reasons why I dissent from this view are: Ist. The "chambers" are admittedly "more continuous and wider in proportion to the septa" than specimens found elsewhere. They are, in fact, little more than an aggregation of concentric plates or perhaps only bands, and according to the figure do not show the true segments. and. The microscope reveals "for the most part merely traces

* Silliman's A merican Fournal, July 1870

Geological Magazine, vol. ii. p. 7

$\$$ Ibid. p. 147 . \$I Ibid, p. 97 . 